\title{
Teaching English at Sekolah Agama Rakyat (People's Religious Schools) in Northern Peninsula Malaysia: Methodology Development and Preliminary Observations
}

\author{
Nurulhayati Ilias (Corresponding author) \\ Kolej Poly-Tech MARA (KPTM) Ipoh, No. 154295, Wisma SSI, Jalan Sultan Abdul Jalil \\ Greentown, Ipoh 30450, Perak, Malaysia \\ E-mail: hayatinurul1@gmail.com \\ Airil Haimi Mohd Adnan \\ Department of English Language \& Linguistics, Universiti Teknologi MARA (UiTM) Perak \\ Seri Iskandar Campus, Bota 32610, Perak, Malaysia \\ E-mail: airil@teechconsult.com
}

Doi:10.7575/aiac.alls.v.5n.6p.260

Received: $13 / 09 / 2014$

URL: http://dx.doi.org/10.7575/aiac.alls.v.5n.6p.260

Accepted: 05/11/2014

\begin{abstract}
This research article is based on a pilot study that we carried out to gain preliminary insights into how English is taught at 'Sekolah Agama Rakyat' ('SAR' or literally translated as 'People's Islamic Religious Schools') in a state in northern Peninsula Malaysia. In the process of carrying out the study, we tested data collection instruments that we developed to understand the complexities of English language teaching in this interesting educational milieu. Questionnaires were distributed to 30 English language teachers from three schools to collect data on their educational background and their teaching experience. Classroom observations were also carried out in one of the schools to examine whether the classroom adheres to the general principles of Communicative Language Teaching (CLT) as required by the Malaysian Ministry of Education. Finally, interview sessions were conducted to examine how the schools' management personnel contribute to teachers' performance as a whole. It was found that almost all the teacher participants that we came into contact with were not certified as English as a Second Language practitioners and some never received any forms of formal teacher training. The classroom observations that we carried out generally show an unconducive climate to support English language learning. In addition, the interview sessions revealed that SAR teachers rarely attend professional development courses. We hope that these preliminary observations from our pilot study will lead to more research efforts in order to understand the realities (and complexities) of teaching English within the Malaysian SAR educational context.
\end{abstract}

Keywords: Islamic schools, Malaysia, ELT, CLT, teacher education, professional development

\section{Research background}

This pilot study was conducted to examine how the English language subject is taught at three privately-funded SARs in the state of Perak in northern Peninsula Malaysia. It must be mentioned from the outset that Islamic education plays a special role within the Malaysian education system well before the Federation of Malaya's independence from British colonial rule in 1957 (see, Adnan \& Smith, 2001; Adnan, 2001). The history of Malaysia's brand of Islamic education, and the establishment of religious schools on a large scale that integrate academic and religious subjects for the Malay majority, are topics that have been well-documented by scholars (Adnan, 2013).

As Harper (1999) notes, "in 1953 there were only 26,215 Malays in English schools ... a quarter of the total pupils" (p. 234). At the same time, although quite small in number, Malay schools or 'sekolah rakyat/Melayu' assisted rural Malays to gain access to formal education. Even if these schools were faced with problems like shortages in teachers and funds, the setting up of these schools, mostly by members of local communities, proved that the Malays are open to learning and not insular (Melebek \& Moain, 2006). Another possibility for young Malays to learn came in the form of Islamic religious schools or traditional 'sekolah pondok'. Although initially perceived as less formally organised compared to government-funded schools, Islamic schooling also provided opportunities for the Malays to access education, a practice that continues in Malaysia today (Rosnani, 1996).

At this present time, according to the Malaysian Advisory Board for the Coordination of Islamic Education or 'Lembaga Penyelaras Pendidikan Agama Islam Malaysia' (LEPAI, 1998 as cited in Ahmad Kilani, 2003), there are three types of schools that are allowed to subscribe to the Islamic Education curriculum. The first is called National Islamic Secondary Schools ('SMKA' or 'Sekolah Menengah Kebangsaan Agama'). These schools are under the direct control of the Malaysian Ministry of Education at federal level. The second is called State Islamic Schools ('SAN' or 
'Sekolah Agama Negeri'). These schools are fully managed by the Department of Religious Affairs of different Malaysian states. The third type of school is the Sekolah Agama Rakyat (SAR or literally translated as People's Islamic Religious Schools). These schools are unique as they are operated by non-governmental organizations and other nonprofitmaking entities.

Within the Malaysian education system, all schools are expected to fully subscribe to the national academic curriculum that is provided by the Malaysian Ministry of Education (Adnan, 2013). This is to allow students to sit for national standardized examinations such as the Lower Secondary Evaluation (PT3), Malaysian Certificate of Education (SPM) and Malaysian High School Certificate (STPM).

\subsection{English language performance in Islamic Religious Schools}

The 'problem' of English language teaching and learning within Malaysian borders is not a new topic nor will it be easy to find a solution to the perennial Malaysian 'English language dilemma' (for further discussion, see Adnan, 2005 and 2012). Although the Malaysian government has instituted many policies to support the teaching and learning of English, even to the point of using the mass media and popular media as English teaching 'tools' (see, Adnan, 2010) there seems to be many institutional and socioeconomic problems that hinder these positive efforts.

Therefore, it is not surprising that lately certain quarters within Malaysian society have raised the issue of the moderate performance in the English language subject in SARs (within the national standardized examinations framework) to continue to fuel the debate. While there is no doubt that a small minority of SAR students have been able to show commendable performance in the said subject, as a whole, the English language performance of students within this educational setting is rapidly declining compared to other schools within the Malaysian system.

According to Ahmad Zabidi (2005), a number of SARs have very limited facilities in terms of teaching materials, laboratories and libraries. In addition, some of the teachers in these schools do not possess basic teacher's training and they are not able to attend teaching courses that can elevate their professionalism. Most of these schools also do not offer promotion and permanent service schemes for their teachers or the opportunity to undergo tertiary training and pursue university-level education. A number of Sekolah Agama Rakyat are also plagued by insufficient funding and poor safety maintenance records (see, Sufean Hussin, 2005; Zaharah Hussin, 2005).

The Ministry of Education through its Educational Training and Research Division relates the poor academic performance of the students in SARs to the lack of quality teachers, slow infrastructural development and ineffective management (Ministry of Education, Malaysia, 1989). In its 1989 report on basic education in Malaysia, the ministry stated that 90 percent of teachers in 49 randomly selected SARs were without professional qualification and training, 73.2 percent did not graduate from university or college, and 26.5 percent were merely SPM-educated secondary school leavers. Analysing SPM results in 2002, only three out of ten SAR students passed all their academic subjects, compared to six out of ten students from the national school system. Strangely enough, only around 10 percent of SAR students scored an 'A' grade in Islamic Education, a subject in which they were expected to shine (for further discussion, see Ministry of Education, Malaysia, 2014).

Table 1 below outlines the results of the English language subject for the Malaysian Certificate of Education (SPM) recorded in nine SARs in the state of Perak, Malaysia from 2009 to 2012 ('n. a.' in the table denotes data not available at the time of going to press). This national-level examination is the Malaysian equivalent of GCE/GCSE and it is the school-leaving examination undertaken by all secondary level students in the country.

Table 1. SPM English language performance in nine SARs within the state of Perak, Malaysia

\begin{tabular}{lcccccc}
\hline & Year & $\mathrm{N}$ & Pass & $\%$ & Fail & $\%$ \\
\hline School A & 2009 & 7 & 4 & 57.1 & 3 & 42.9 \\
& 2010 & 4 & 1 & 25.0 & 3 & 75.0 \\
& 2011 & 12 & 4 & 33.3 & 8 & 66.7 \\
& 2012 & 10 & 5 & 79.1 & 4 & 20.9 \\
\hline School B & 2009 & 35 & 27 & 81.8 & 8 & 24.2 \\
& 2010 & 31 & 20 & 64.5 & 11 & 35.5 \\
& 2011 & 32 & 18 & 56.3 & 14 & 43.8 \\
& 2012 & 24 & 13 & 40.6 & 9 & 40.9 \\
\hline School C & 2009 & 22 & 9 & 40.9 & 13 & 59.1 \\
& 2010 & 20 & 7 & 35.0 & 13 & 65.0 \\
& 2011 & 26 & 5 & 19.2 & 21 & 80.8 \\
& 2012 & 29 & 3 & 10.4 & 26 & 89.6 \\
\hline
\end{tabular}




\begin{tabular}{|c|c|c|c|c|c|c|}
\hline \multirow[t]{4}{*}{ School D } & 2009 & 86 & 86 & 100.0 & 0 & 0.0 \\
\hline & 2010 & 69 & 69 & 100.0 & 0 & 0.0 \\
\hline & 2011 & 71 & 71 & 100.0 & 0 & 0.0 \\
\hline & 2012 & 74 & 74 & 100.0 & 0 & 0.0 \\
\hline \multirow[t]{4}{*}{ School E } & 2009 & 41 & 39 & 95.1 & 2 & 4.9 \\
\hline & 2010 & 44 & 43 & 97.7 & 1 & 2.3 \\
\hline & 2011 & 41 & 38 & 92.7 & 3 & 7.3 \\
\hline & 2012 & 31 & n. a. & n. a. & n. a. & n. a. \\
\hline \multirow[t]{4}{*}{ School F } & 2009 & 17 & 8 & 47.1 & 9 & 52.9 \\
\hline & 2010 & 41 & 22 & 53.7 & 19 & 46.3 \\
\hline & 2011 & 38 & 16 & 42.1 & 22 & 57.9 \\
\hline & 2012 & n. a. & n. a. & n. a. & n. a. & n. a. \\
\hline \multirow[t]{4}{*}{ School G } & 2009 & 39 & 26 & 66.7 & 13 & 33.3 \\
\hline & 2010 & 24 & 15 & 62.5 & 9 & 37.5 \\
\hline & 2011 & 49 & 38 & 77.6 & 11 & 22.4 \\
\hline & 2012 & 49 & 36 & 73.5 & 13 & 26.5 \\
\hline \multirow[t]{4}{*}{ School H } & 2009 & n. a. & n. a. & n. a. & n. a. & n. a. \\
\hline & 2010 & 50 & 47 & 94.0 & 3 & 6.0 \\
\hline & 2011 & 53 & 40 & 75.5 & 13 & 24.5 \\
\hline & 2012 & n. a. & n. a. & n. a. & n. a. & n. a. \\
\hline \multirow[t]{4}{*}{ School I } & 2009 & n. a. & n. a. & n. a. & n. a. & n. $a$. \\
\hline & 2010 & n. a. & n. a. & n. a. & n. a. & n. a. \\
\hline & 2011 & n. a. & n. a. & n. a. & n. a. & n. a. \\
\hline & 2012 & 24 & 19 & 79.1 & 5 & 20.8 \\
\hline
\end{tabular}

From the table, we can see that there is an overall decline in the performance of SAR students in the English language subject at SPM or Malaysian Certificate of Education level. This is a cause for concern given the fact that these secondary school-leavers are expected to continue their studies at tertiary level where English continues to be taught and used. Questions arise as to their competence as tertiary level students and their readiness to study at a higher level when they failed to show their English language abilities at a lower (i.e., secondary) level.

\subsection{Guiding questions for this pilot research}

The above factors compelled us to conduct a pilot study to identify possible causes that contribute to the weak performance in the English language subject by SAR students. Our goal is to later on carry out large-scale fieldwork to see how English is taught within these schools and how the schools' management impact upon the performance of the English language subject as measured through the national standardized examinations framework and school-level assessment regimes. It is hoped that our effort will shed some light into improving the English language teaching and learning situation within these schools. Towards these aims, we operationalised three guiding/research questions:

First: How is English taught at three randomly selected Sekolah Agama Rakyat (SAR or People's Islamic Religious Schools) in the state of Perak, Malaysia?

Second: Are English language teachers in these schools equipped with professional knowledge on English language teaching and learning?

Third: How does the schools' management impact upon the overall teaching performance of English language teachers within this educational context?

\section{Research methods}

With the primary aims of executing a pilot study on Sekolah Agama Rakyat and gauging English language teachers' professional knowledge and experiences in teaching English within this educational context, we adopted a mixedmethods design for this study. We worked with teacher participants from three secondary level SARs in a state in northern Peninsula Malaysia to carry out our study (i.e., the state of Perak). Three types of data collection instruments 
were employed for our pilot study:

1. Classroom observations

2. Questionnaires

3. Semi-structured interviews

The study that we carried out involved all English language teachers who, at that time, were teaching in three privatelyfunded SARs in Perak. General details regarding the schools are provided in Table 2 below.

Table 2. Basic details of the three sites of research that we chose

\begin{tabular}{lcc}
\hline & Location & Number of English teachers \\
\hline School A & Urban area (city centre) & 12 \\
\hline School B & Rural town & 10 \\
\hline School C & Rural town & 8 \\
\hline
\end{tabular}

\subsection{Classroom observations}

The observation checklist below was used to examine pre-teaching, while-teaching and post-teaching activities of teachers in the three schools. We outlined several instructional elements to be assessed and presented them in the form of an observation checklist as seen in Figure 1.

\begin{tabular}{|c|c|c|c|c|}
\hline & INSTRUCTIONAL ELEMENTS & OBSERVED & $\begin{array}{c}\text { NOT } \\
\text { OBSERVED }\end{array}$ & FIELD NOTES \\
\hline $\mathbf{A}$ & SET INDUCTION & & & \\
\hline \multirow{4}{*}{ 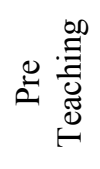 } & Activity to attract SS [students'] attention & & & \\
\hline & Activity to recall previous learning & & & \\
\hline & Introducing the topic & & & \\
\hline & Stating the lesson objectives & & & \\
\hline B & TEACHING AND LEARNING & & & \\
\hline \multirow{11}{*}{$\frac{e}{\frac{0}{3}}$} & Employs all four language skills & & & \\
\hline & Employs effective method of teaching listening & & & \\
\hline & Employs effective method of teaching reading & & & \\
\hline & Employs effective method of teaching writing & & & \\
\hline & Employs effective method of teaching speaking & & & \\
\hline & $\begin{array}{l}\text { Employs different techniques to SS with different } \\
\text { language ability }\end{array}$ & & & \\
\hline & Audio-visual use (if necessary) & & & \\
\hline & Employs SS' interaction activities & & & \\
\hline & Engages students with learner-centred activities & & & \\
\hline & Employs group work activities & & & \\
\hline & Maximum use of the target language & & & \\
\hline C & ASSESSMENT & & & \\
\hline \multirow{2}{*}{$\stackrel{0}{0}_{2}^{n}$} & Provide enhancement activities & & & \\
\hline & Provide assessment activities & & & \\
\hline
\end{tabular}

Figure 1. Classroom observation checklist

\subsection{Questionnaires}

The second instrument employed in this pilot study was a standardised questionnaire. We constructed this instrument so that it could inductively shed some answers to the second research question: "Are English language teachers in these schools equipped with professional knowledge on English language teaching and learning?" Following that, actual survey items were constructed and categorized into three broad categories namely demographic data (Part A), professional development (Part B) and teacher readiness (Part C). Figure 2 is an abridged version of our second data collection instrument. 


\begin{tabular}{|c|c|c|c|c|c|c|c|c|}
\hline $\mathrm{Pt}$ & Cat & \multicolumn{7}{|l|}{ QUESTIONS } \\
\hline A & 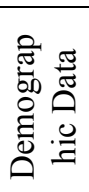 & \multicolumn{7}{|c|}{$\begin{array}{l}\text { Age / Years of teaching experience / Previous schools taught / Educational background / Teaching } \\
\text { certification / Language proficiency level / Other language spoken besides English / Reasons for choosing } \\
\text { English teaching as a career / Formal qualifications required by your institution to teach English / Hours of } \\
\text { teaching per week / Number of students / Hours of English language teaching training received. }\end{array}$} \\
\hline \multirow[t]{3}{*}{$\mathrm{B}$} & \multirow[b]{3}{*}{ 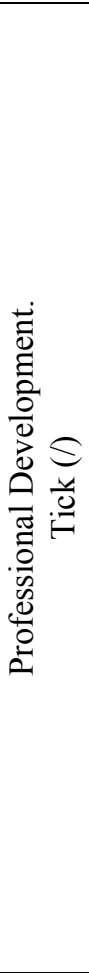 } & ELT Training Courses & \multicolumn{6}{|c|}{ Duration (Hours) } \\
\hline & & Skills focus & 0 & $1-2$ & $2-3$ & $3-4$ & $4-5$ & $>5$ \\
\hline & & $\begin{array}{l}\text { ESL Theories } \\
\text { Curriculum Design } \\
\text { Applied Linguistics } \\
\text { Phonetics } \\
\text { Sociolinguistics } \\
\text { Psycholinguistics } \\
\text { SLA } \\
\text { Teaching-Aid Materials Development } \\
\text { Teaching Approaches And Methods } \\
\text { Teaching Reading } \\
\text { Teaching Writing } \\
\text { Teaching Listening } \\
\text { Teaching Speaking } \\
\text { Teaching Grammar } \\
\text { Teaching Literature } \\
\text { Question Development } \\
\text { Teaching Literature } \\
\text { Technology And Computer Aided Instruction } \\
\text { Lesson Plan } \\
\text { Practicum } \\
\text { Others? (Please specify) }\end{array}$ & & & & & & \\
\hline $\mathrm{C}$ & & Items & $\begin{array}{l}\stackrel{8}{0} \\
\dot{5} \\
\dot{5} \\
\dot{s}\end{array}$ & $\begin{array}{l}\stackrel{\Xi}{0} \\
\stackrel{5}{4}\end{array}$ & & & 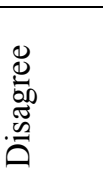 & 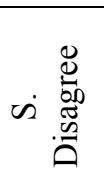 \\
\hline & 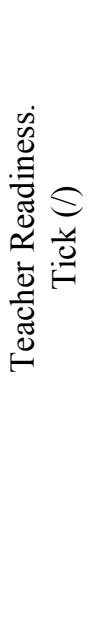 & $\begin{array}{l}\text { I like teaching } \\
\text { I am eager to teach English } \\
\text { I will attempt my duty sincerely } \\
\text { I have adequate knowledge of teaching reading } \\
\text { I have adequate knowledge of teaching listening } \\
\text { I have adequate knowledge of teaching writing } \\
\text { I have adequate knowledge of teaching speaking } \\
\text { I have adequate knowledge of teaching grammar } \\
\text { I have adequate knowledge of teaching techniques } \\
\text { I have adequate knowledge of classroom management } \\
\text { I have adequate knowledge of preparing test questions } \\
\text { I have adequate knowledge of students' learning styles } \\
\text { I have adequate knowledge of students proficiency level } \\
\text { I have adequate knowledge of students' motivation } \\
\text { I have knowledge of computer/technology aided instruction }\end{array}$ & & & & & & \\
\hline
\end{tabular}

\section{Methodology development and preliminary observations}

At this present time, we managed to fully pilot the survey instrument and also carried out a number of classroom observations and semi-structured interview sessions. As for the questionnaires, all 30 teacher participants in the three research sites completed and successfully returned our survey forms. We met each one of them personally to discuss the questionnaires from the outset and then collected the forms from them when they were ready. The Cronbach Alpha values for the questionnaire are as follows.

For part 'B' that relates to the subject knowledge and professional development of the teacher participants, the initial value is .974 . 
Reliability Statistics

\begin{tabular}{|c|c|}
\hline $\begin{array}{c}\text { Cronbach's } \\
\text { Alpha }\end{array}$ & $\mathrm{N}$ of Items \\
\hline .9 & 20 \\
\hline
\end{tabular}

For part ' $\mathrm{C}$ ' that relates to the readiness and experience of the teacher participants to teach in the research settings, the returned value is .892 .

\begin{tabular}{cr}
\hline \multicolumn{2}{c}{ Reliability Statistics } \\
\hline $\begin{array}{c}\text { Cronbach's } \\
\text { Alpha }\end{array}$ & N of Items \\
.892 & 16 \\
\hline
\end{tabular}

In terms of the population make up within the research sites, we found that all 30 respondents had different educational experiences, ranging from the Malaysian Certificate of Education (SPM) to degree level qualifications. Interestingly for us, even though all three schools have set the SPM certificate as the minimum qualification for English teachers, the schools did not explicitly require prospective English teachers to have any kind of formal training in English language teaching and learning. Out of the 30 teacher participants in our pilot study, only one was qualified as a teacher of English as a Second Language (ESL). The other 29 'English' teachers were also first degree holders albeit with specialisations in areas that are not related to English language teaching and learning. In fact, all the teacher participants in our pilot study admitted to having low to moderate levels of proficiency in the English language. In addition, nearly all of them have never attended any kinds of formal English language teaching and learning courses to raise their professionalism in the last 2 years to date.

This dire reality was reflected in our classroom observations. In one observation session that typifies the style of teaching and learning of English in these schools, we observed a class that ran for a full hour (from 2 p.m. in the afternoon to 3 p.m.). Our observation showed that this particular teacher did not 'teach English' per se but she spent the entire hour to teach her students techniques for answering English language exam questions. At the start of the class, no induction activities were done to stimulate students' interest. Then, for the duration of that period, about $90 \%$ of 'teacher talk' was done in the students' first language which is 'Bahasa Melayu' or Malay language. Moreover, the teaching style of the teacher was quite traditionally teacher-centred and all her students were not given the time and space to interact in the target language (i.e., English). Nevertheless, we are both trying to remain optimistic for our actual research effort. Perhaps, further longitudinal observations will show positive aspects of English teaching and learning within the research sites.

With reference to the interviews, the preliminary session that we conducted with this particular teacher revealed that she strongly felt that she was not fully proficient in the subject that she has been asked to teach. She also acknowledged that the use of Malay language was extremely important as a way to ensure that her students understood what she was teaching. She reasoned that her students all come with a background in religious education that stresses more on Arabic language proficiency compared to English. The teacher also told us that it was quite difficult for English teachers (in schools like hers) to get the opportunity to increase their abilities to teach English what more to attend professionallevel English language teaching courses due to financial constraints and negative perceptions regarding this international language by administrative personnel. In the end, she accepted that these factors are likely to have contributed to the overall less-than-average quality of her teaching and that of other colleagues in her department.

\section{Preliminary conclusions and tentative recommendations}

We believe that it is important for English language teachers to have adequate knowledge about the teaching of English no matter where they are teaching. English teachers must still try to equip themselves with adequate skills to teach the target language because they are the role models for their students who will try their best to become like their teachers. To master English, students should be exposed to the target language as much as possible. Hopefully, this will enhance their receptive skills (i.e., listening and reading). On the contrary, the total opposite is happening in Malaysian Sekolah Agama Rakyat or People's Islamic Religious Schools where English is being taught almost exclusively in the mother tongue of students.

Students in SARs should be given the opportunity to take part actively in the target language to improve their productive skill too (i.e., speaking and writing). Teachers in these schools should strive to create interactive teacherstudent and student-student 'learning moments' that will give their students the chance that they desperately need for much needed practice. Again, on the contrary, English teachers within this educational context prefer to teach in the traditional manner from the front of the classroom. This might hinder the promotion of English and even be counterproductive in the long run.

At the same time, as mentioned in the previous section, we remain optimistic that changes can happen in Malaysian SARs given the fact that there are still a number of privately-run SARs that managed to record total passes in the SPM examinations every year, including for the English language paper. Moreover, given that ours is a pilot effort to learn 
more about the research context before we begin our extensive fieldwork, more data must be collected before better conclusions could be drawn about the English language teaching situation in Malaysian Sekolah Agama Rakyat or People's Islamic Religious Schools.

\section{References}

Adnan, A. H. M. \& Smith, E. (2001). The social functions of education in a developing country: the case of Malaysian schools and the role of Malaysian teachers. Intercultural Education, 12(3), 325-337.

Adnan, A. H. M. (2001). The use of, and attitudes toward, the English language in Bumiputera Malay boarding schools in Malaysia: reality of the Malaysian 'English language dilemma' (unpublished M.A. dissertation). University of Leicester, England.

Adnan, A. H. M. (2005). The 'English Language Dilemma' in Malaysia: Vision, reality and the ethnicity-religionlanguage tapestry of the Malays. In K. Ariffin, M. Ismail, M. Latif, N. K. Leng \& R. Aziz (eds.). English in Education: Issues and Challenges in the Malaysian Classroom (pp. 1-13). Shah Alam: UPENA Universiti Teknologi MARA (UiTM Press).

Adnan, A. H. M. (2010). Employing discourse, language and television media to reconstruct the image of Islam: a case study of Malaysia. Asian Social Science, 6(6), 33-41.

Adnan, A. H. M. (2012). Perdre sa langue, perdre son identité, se perdre. Le cas des enfants Orang Asli (aborigènes) de Malaise. Droit et Cultures, 63(1), 87-109.

Adnan, A. H. M. (2013). Language use and workplace participation in the identity construction of Bumiputera Malay undergraduates in Malaysia (unpublished Ph.D. thesis). University of Auckland, New Zealand.

Ahmad Kilani, M. (2003). Pengurusan Pendidikan Di Sekolah: Huraian Menurut Perspektif Islam. Skudai: Universiti Teknologi Malaysia Press.

Ahmad Zabidi, A. R. (2005). Ciri-ciri sekolah berkesan: implikasinya terhadap pengurusan sekolah agama. In S. Hussin, S. @ Charil Marzuki, A. Z. Abdul Razak, H. Md Som \& A. Ranee (eds.). Pentadbiran dalam Pembangunan Pendidikan (pp. 75-92). Bentong: PTS Professional Publishing.

Harper, T. N. (1999). The End of Empire and the Making of Malaya. Cambridge: Cambridge University Press.

Melebek, A. R. \& Moain, A. J. (2006). Sejarah Bahasa Melayu. Kuala Lumpur: Utusan Publications.

Ministry of Education, Malaysia (1989). Laporan mengkaji beberapa sekolah menengah yang berkesan dan tidak berkesan di Semenanjung Malaysia. Special Report filed by the Educational Training and Research Division of the Ministry of Education.

Ministry of Education, Malaysia (2014). SABK \& SMKA. [Online] Available at http://www.moe.gov.my/v/sabk-smka (November 1, 2014).

Rosnani, H. (1996). Education Dualism in Malaysia. Oxford: Oxford University Press.

Sufean Hussin (2005). Pentadbiran dalam pembangunan pendidikan: satu ulasan ke arah penambahbaikan. In S. Hussin, S. @ Charil Marzuki, A. Z. Abdul Razak, H. Md Som \& A. Ranee (eds.). Pentadbiran dalam Pembangunan Pendidikan (pp. 3-18). Bentong: PTS Professional Publishing.

Zaharah Hussin (2005). Keperluan pendidikan akhlak dan rohani dalam latihan perguruan pendidikan Islam di Malaysia. In S. Hussin, S. @ Charil Marzuki, A. Z. Abdul Razak, H. Md Som \& A. Ranee (eds.). Pentadbiran dalam Pembangunan Pendidikan (pp. 381-396). Bentong: PTS Professional Publishing. 